\title{
Window phase analysis of nutrient losses from a typical rice-planting area in the Yangtze river delta region of China
}

\section{Shuang He}

Zhejaing University

\section{Fayong Li}

Zhejiang University

\section{XINQIANG LIANG ( $\square$ liang410@zju.edu.cn )}

Zhejiang University https://orcid.org/0000-0002-3521-9761

\section{Hua Li}

Zhejiang Academy of agricultural science

\section{Sheng Wang}

Zhejiang University

\section{Yingbing Jin}

Zhejiang University

\section{Boyi Liu}

Zhejiang University

\section{Guangming Tian}

Zhejiang University

\section{Research}

Keywords: drainage water, rice field, self-organizing maps, stream, total phosphorus, total nitrogen

Posted Date: January 20th, 2020

DOI: https://doi.org/10.21203/rs.2.19772/v2

License: (c) (1) This work is licensed under a Creative Commons Attribution 4.0 International License. Read Full License

Version of Record: A version of this preprint was published at Environmental Sciences Europe on February 3rd, 2020. See the published version at https://doi.org/10.1186/s12302-020-0291-0. 


\section{Abstract}

Background: Rice paddy wetlands may serve as a nutrient source or sink in agricultural ecosystems. However, the pattern of nutrient loss on a watershed scale is not clear. A year-round on-site observation study based on 6-h intervals was conducted. Rainfall, temperature, runoff nutrient concentrations, and adjacent stream water samples were automatically monitored to uncover the temporal changes in the runoff losses of the predominant nutrient proxies (total $\mathrm{N}$ and total $\mathrm{P}$ ) from a typical rice-planting area (120 ha) in the Yangtze delta region of China.

Results: A high total $\mathrm{N}$ concentration in the rice-planting area was observed during the rice-planting season; however, significant fluctuation in the total $\mathrm{P}$ was evident throughout the year. The $\Delta$ total $\mathrm{N}$ (drainage minus stream) parameter showed negative values with a mean of $-0.25 \mathrm{mg} \mathrm{L}-1$, while $\Delta$ total $P$ showed positive values with a mean of $0.06 \mathrm{mg} \mathrm{L}-1$. The annual average $N$ and $P$ runoff from paddy field were $11.6 \mathrm{~kg}$ ha -1 and $1.5 \mathrm{~kg}$ ha -1 , respectively. The window phases for the total $\mathrm{N}$ loss were mainly concentrated in the rice-growing season. However, the window phase for the total P loss was more dispersive throughout the year. No apparent relationships were found between rainfall and $\mathrm{N}$ and $\mathrm{P}$ concentrations by self-organizing map analysis.

Conclusions: The high-resolution monitoring, in this study, suggested that nutrient loss loading rather than nutrient concentration, was strongly related to surface runoff Therefore, fertilization before highintensity rainfall should be avoided to mitigate the nutrient runoff losses and maintain the rice wetland eco-function.

\section{Background}

High levels of nutrient losses from agro-ecosystems, such as paddy fields, in which nutrients flow into downstream lakes, reservoirs, and other open water bodies can cause eutrophication, including excessive algal blooms, in the adjacent receiving streams [1-4]. Rice paddy fields account for $50 \%$ and $14 \%$ of global irrigation water and fertilizer consumption, respectively, owing to frequent irrigation and excessive fertilization [5]. The paddy field is also one of the most important sources of nutrient losses to streams in the Yangtze river delta region of China, owing to the addition of chemical and organic nitrogen $(\mathrm{N})$ and phosphorus $(P)$ fertilizers (residue and manure), intensive puddling, and alternating flooding and draining management [6]. Today, the rice-planting area covers more than 18 million ha in this region [6, 7], whereby the application rates of $\mathrm{N}$ and $\mathrm{P}$ fertilizers have reached or exceeded $300 \mathrm{~kg} \mathrm{ha}^{-1}$ and $200 \mathrm{~kg} \mathrm{ha}^{-1}$, respectively [8]. Moreover, the rainfall in some regions such as Zhejiang province can be higher than 1500 $\mathrm{mm} \mathrm{yr}^{-1}$, mostly occurring during the rice-planting season. Therefore, excessive surface runoff from the paddy field in the Yangtze river delta region of China may occur.

Lowland rice paddy fields are vital for both world food production and regional nutrient management. Many researches have proved that rice fields would not always export $\mathrm{N}$ and $\mathrm{P}$ to ambient water bodies, and rice paddy fields were considered as wetlands to retain nutrients $[9,10]$. Thereby, due to the soil 
nutrient retain and rice uptake [11], the runoff nutrient concentrations may be lower than the receiving stream. However, when heavy rainfall occurs following fertilization, the runoff nutrient concentrations become higher than those in the receiving stream [12], which can be defined as a discharge window phrase (or a critical discharge period) of $\mathrm{N}$ and $\mathrm{P}$ from paddy fields. At present, the window phrases of $\mathrm{N}$ and $\mathrm{P}$ losses from rice paddy fields are still unclear, which brings challenges to nutrient management in this ecosystem.

Nitrogen and phosphorus losses from paddy fields usually occur predominantly through surface runoff rather than infiltration because of a plow pan that prevents downward water infiltration [13]. Some studies have shown that $\mathrm{N}$ and $\mathrm{P}$ runoff losses are affected by soil and climatic parameters, as well as agricultural practices, including soil texture, cover crops, the application rate of $\mathrm{N}$ and $\mathrm{P}$ fertilizers, timing and method, soil tillage, irrigation regimes, and rainfall intensity and amount [14-16]. A small-scale insitu experiment show that total P (TP) runoff losses ranged from 0.18 to $1.51 \mathrm{~kg} \mathrm{ha}^{-1}$, and particulate $\mathrm{P}$ (PP) runoff losses accounted for $58-77 \%$ of the seasonal TP lost [14]. They further reveal that nutrient loss loading varied with seasons [14]. However, current research on nutrient runoff in large-scale riceplanting areas has been rarely performed. Moreover, the discharge window phase and dissipation law of $\mathrm{N}$ and $\mathrm{P}$ loss loading in planting areas are rarely reported.

Rainfall is one of the most critical factors affecting $\mathrm{N}$ and $\mathrm{P}$ loss, as it is associated with the drainage of rice fields. Field runoff caused by heavy rainfall in the rainy season causes a certain amount of $N$ and $P$ nutrient loss. Guo et al. [17] found that the annual P loss was $0.75 \mathrm{~kg} \mathrm{hm}^{-2}$ using field surveys of rice fields in the Taihu Lake area. However, when several rainfall events took place during cultivation and fertilization, the annual P loss increased to $5.49-17.68 \mathrm{~kg} \mathrm{hm}^{-2}$ under current irrigation and drainage conditions [18]. Nevertheless, it is still unclear how rainfall affects the soil $\mathrm{N}$ and $\mathrm{P}$ loss loadings. Inevitably, seasonal fluctuations in the soil $\mathrm{N}$ and $\mathrm{P}$ loss loadings will result in changes in the water quality of the external receiving water bodies, owing to the seasonal variations of rainfall.

Hence, it is crucial to uncover the effects of rainfall and subsequent runoff amount on the nutrient loss loading from the rice fields in the Yangtze river delta region. However, the nutrient runoff from rice fields, unlike that from upland fields, can be reduced by field bunds [19]; thus, the relationship between rainfall and nutrient runoff loss is more complicated in the rice fields. Many researchers [20,21] have employed monitoring data to investigate the role of rain events in the $\mathrm{N}$ and $\mathrm{P}$ loss to adjacent streams. Other studies $[22,23]$ have observed a decrease in the total $\mathrm{N}$ and $\mathrm{P}$ concentrations with time or with the number of rainfall events. However, there is no definite conclusion concerning the relationship between the rainfall amount and the total $\mathrm{N}$ and $\mathrm{P}$ concentration in the runoff and adjacent stream water because of the complex processes of $\mathrm{N}$ and $\mathrm{P}$ transport [24]. To date, the relationship between the rainfall and nutrient runoff losses from agricultural fields is often explored by using monthly or bimonthly rainfall monitoring data [25-28]. We consider that this approach cannot accurately predict agricultural nutrients, such as $\mathrm{N}$ and $\mathrm{P}$ runoff over the rainfall amount. One alternative is to use high-resolution daily rainfall vs. water-quality monitoring data, which can facilitate the retrieval of timely dynamic variations of nutrient runoff losses under changing rainfall conditions $[29,30]$. 
The objective of this study was to investigate the response of the total $\mathrm{N}$ and $\mathrm{P}$ concentrations to rainfall in the runoff versus the adjacent stream to the rice field system using 6-h interval monitoring data and the Self-Organizing Map (SOM) prediction approach. We hypothesized that: 1) There are window phases and dissipation periods for the runoff of $\mathrm{N}$ and $\mathrm{P}$ in the retention ditch of the paddy field. Additionally, the concentrations of $\mathrm{N}$ and $\mathrm{P}$ in the runoff are higher and lower than those in the external stream during the window phase and dissipation period respectively. 2) The loss loadings of $N$ and $P$ in the runoff, rather than the concentrations of $\mathrm{N}$ and $\mathrm{P}$ of the paddy field ditches, are closely related to the amount of surface runoff caused by rainfall.

\section{Materials And Methods}

\section{The site description of rice plantation}

The rice plantation area investigated in this study is located at Jinshan town, Hangzhou city, in the Yangtze river delta region of China. It covers a total of 120 ha rice fields with a single crop of late-season rice. This area has a subtropical monsoon climate, and the soil type of the rice field is hydromorphic paddy soil (ferric-accumulic stagnic anthrosols). The soil properties of the plow layer $(0-20 \mathrm{~cm})$ were as follows: pH 5.8 (1:5, soil/water), soil organic C $21.8 \mathrm{~g} \mathrm{~kg}^{-1}$, total $\mathrm{N} 3.46 \mathrm{~g} \mathrm{~kg}^{-1}$, mineral $\mathrm{N} 24.0 \mathrm{mg} \mathrm{kg}^{-1}$, and total $P 0.318 \mathrm{~g} \mathrm{~kg}^{-1}$. A trench for receiving the excessive surface run off water from the rice plantation area was $5 \mathrm{~m}$ wide, $2.5 \mathrm{~m}$ deep, and $1850 \mathrm{~m}$ long.

\section{Experimental design}

Rice seedlings of a local late-season rice cultivar named Xiushui 134 (i.e., Oryza sativa L.) were mechanically transplanted on June 4, 2018. The entire rice plantation area was uniformly fertilized. Specifically, urea was applied in three splits for the late-season rice, i.e., 40\% was basally applied (June 4, 2018), while another $40 \%$ was top-dressed at the tillering stage (July 5, 2018), and the remaining $20 \%$ was top-dressed at the panicle initiation stage (August 5,2018). Full doses of superphosphate and potassium chloride were applied basally at the rates of $120 \mathrm{~kg} \mathrm{P}_{2} \mathrm{O}_{5} \mathrm{ha}^{-1}$ and $120 \mathrm{~kg} \mathrm{~K}_{2} \mathrm{O} \mathrm{ha}{ }^{-1}$, respectively. The entire duration of the rice growth was 139 days, and the final harvests were completed on October 21, 2018. We followed the typical irrigation method for flooded rice in the region that consisted of irrigating the paddy field until the depth of $70 \mathrm{~mm}$; then, when the field water level dropped to $10 \mathrm{~mm}$, irrigation was repeated. Thus, the floodwater depths in the field fluctuated from 10 to $70 \mathrm{~mm}$ until rice maturity and drained $30 \mathrm{~d}$ before harvest [2].

A water monitoring station was set-up at the end of the long trench to simultaneously take water samples from both the trench runoff and adjacent stream. The samples were taken every $6 \mathrm{~h}$ from Feb 10, 2018, to Jan 30, 2019, except when the trench water was frozen (Fig. 1). The nutrient proxies (i.e., total N, and total $P)$ in these water samples were automatically analyzed by an on-line water-quality analyzer $\left(\mathrm{NH}_{3} \mathrm{~N}-2000\right.$; TPN-2000, China, Hangzhou Juguang Tech. Co.) at the monitoring station. Briefly, the total $\mathrm{N}$ and $\mathrm{P}$ concentrations in the unfiltered water samples from runoff and adjacent stream were determined 
calorimetrically according to the standard method [31] after they were digested with the $\mathrm{K}_{2} \mathrm{~S}_{2} \mathrm{O}_{8}$ solution. Meanwhile, a mini-meteorological station (HOBO-U30, America, Onset Computer Co.) was placed at the experimental site to collect the hourly rainfall data.

\section{Calculation of nutrient runoff loss loading}

The nutrient runoff loss loading was calculated from the nutrient concentration ( $\mathrm{mg} \mathrm{L}^{-1}$ ) multiplied by the runoff amount $(\mathrm{Rd})(\mathrm{mm})$ and rice plantation area. The following equation (Eq. 1) was used to calculate the runoff amount:

\section{See Formula 1 in Supplemental Files.}

Where; $\mathrm{Rf}$ is the rainfall $(\mathrm{mm})[32]$.

\section{Data analysis}

The linear correlations between the accumulated runoff and the total $\mathrm{N}$ and $\mathrm{P}$ loss loadings from the rice field system were analyzed using SPSS statistics (V.22) software. The results of the SOM prediction were evaluated using the correlation coefficients $(R)$ and mean absolute scaled errors (MASE).

We used the SOM approach to visualize the relationships between the accumulated rainfall amount and the total $\mathrm{P}$ and $\mathrm{N}$ concentrations in the retention ditch and adjacent stream water. The SOM analysis was performed using the SOM toolbox (http://www.cis.hut.fi/projects/somtoolbox/) in Matlab (v. 7.11). The description of the SOM approach can be found in previous studies [33-37]. In this study, we developed a dataset that included a $977 \times 11$ matrix, representing 977 samples with 11 measured parameters, i.e., H6, $\mathrm{H} 12, \mathrm{H} 18, \mathrm{H} 24, \mathrm{H} 30, \mathrm{H} 36, \mathrm{H} 42, \mathrm{H} 48$, total $\mathrm{P}$ and $\mathrm{N}$ concentrations in the runoff, and adjacent stream water. The abbreviations, $\mathrm{H6}-\mathrm{H} 48$ indicate the accumulated rainfall amounts at $6-48 \mathrm{~h}$ water sampling intervals. The dataset was loaded into the Matlab workspace, and the abstract visualization process was performed after the installation of the SOM package. To perform this prediction, 684 data samples were randomly selected to be the training data, while the remaining 293 data samples were used as the testing data. Initially, the data entries of the total $P$ and $N$ in the drainage water were eliminated from the testing dataset. After running the SOM analysis, the predicted total P concentrations were compared with the observed values.

\section{Results}

\section{Temperature and rainfall records during the observation period}

The 6 -h cumulative rainfall over the entire year reached a value of $1468 \mathrm{~mm}$. The wettest months were July and August, with a $6-\mathrm{h}$ cumulative rainfall of $328 \mathrm{~mm}$. The mean values of the rainfall amount increased from $\mathrm{H} 6$ to $\mathrm{H} 48$; however, the maximum values did not increase further after $\mathrm{H} 30$, indicating that the most considerable rainfall amount was within $30 \mathrm{~h}$ before the sampling event (data not shown). 
The water temperature reached a maximum of $37.29^{\circ} \mathrm{C}$ between July and August, while the lowest temperature was $-5.01^{\circ} \mathrm{C}$.

\section{Nutrient concentrations and window phases}

The mean value of the total $\mathrm{N}$ in the runoff was lower than that of the adjacent stream. The total $\mathrm{N}$ in the retention ditch water ranged from 0.31 to $7.89 \mathrm{mg} \mathrm{L}^{-1}$, with a mean of $2.11 \mathrm{mg} \mathrm{L}^{-1}$. Meanwhile, the corresponding values in the adjacent stream were $0.48-5.57 \mathrm{mg} \mathrm{L}^{-1}$ and $2.36 \mathrm{mg} \mathrm{L}^{-1}$ (Table 1). More than $38 \%$ of the total $\mathrm{N}$ concentration was higher than $2.0 \mathrm{mg} \mathrm{L}^{-1}$ (i.e., Class $\mathrm{V}$ of Chinese surface water quality guideline for streams) (Figure 7). Contrary to the total $\mathrm{N}$, the mean value of the total $\mathrm{P}$ in the runoff of the retention ditch water was higher than that of the adjacent stream. The total $P$ in the retention ditch water ranged from 0.01 to $1.18 \mathrm{mg} \mathrm{L}^{-1}$, with a mean of $0.24 \mathrm{mg} \mathrm{L}^{-1}$ (Table 1). Meanwhile, the corresponding values in the adjacent stream were $0-1.13 \mathrm{mg} \mathrm{L}^{-1}$ and 0.18 , respectively, i.e., $6 \%$ higher than $0.4 \mathrm{mg} \mathrm{L}^{-1}$ (i.e., Class $\mathrm{V}$ of Chinese surface water quality guideline for streams).

However, the results (Fig. 3) based on the water sampling and measurements in a 6-h interval, show that the temporal changes of the total $\mathrm{N}$ and $\mathrm{P}$ concentrations in the rice-field drainage and adjacent stream water were not identical for most of the sampling events. Specifically, most of the $\Delta$ total $N$ (i.e., total $N$ in drainage minus total $\mathrm{N}$ in the stream) showed negative values with a mean of $-0.25 \mathrm{mg} \mathrm{L}^{-1}$. Meanwhile, the values between June 22 and July 22 were positive with a mean of $1.75 \mathrm{mg} \mathrm{L}^{-1}$, a maximum of 4.26 $\mathrm{mg} \mathrm{L}^{-1}$ on July 12 , and a minimum of $0.01 \mathrm{mg} \mathrm{L}^{-1}$ on July 18 . These results show significant window phrases in these periods. Although $\Delta$ total $\mathrm{P}$ (i.e., total $\mathrm{P}$ in drainage minus total $\mathrm{P}$ in the stream) showed

positive values with the mean of $0.06 \mathrm{mg} \mathrm{L}^{-1}$, negatives values were evident for the minimum (i.e., -0.86 $\mathrm{mg} \mathrm{L}^{-1}$ ) and $25 \%$ percentile (i.e., $-0.01 \mathrm{mg} \mathrm{L}^{-1}$ ), respectively. Even at the $75 \%$ percentile value, the total $\mathrm{P}$ in the rice-field drainage was marginally higher than that in the adjacent stream by $0.08 \mathrm{mg} \mathrm{L}^{-1}$.

Further, the results (Fig. 3 ) show that most of the $\Delta$ total $P$ values (i.e., $47.2 \%$ and $32.5 \%$ of the total observations) were within 0 to $0.1 \mathrm{mg} \mathrm{L}^{-1}$ and -0.1 to $0 \mathrm{mg} \mathrm{L}^{-1}$, respectively. The rest of the $\Delta$ total $P$ values were above $0.1 \mathrm{mg} \mathrm{L}^{-1}$ (i.e., $17.9 \%$ ) or below $-0.1 \mathrm{mg} \mathrm{L}^{-1}$ (i.e., $2.5 \%$ ). The window phases of $\mathrm{N}$ and $\mathrm{P}$ showed different patterns. The window phases of $\mathrm{N}$ mainly appeared from June to July during the ricegrowing season, while the window phases of $\mathrm{P}$ were more scattered and occurred throughout the riceplanting year (Fig. 3). However, the highest peak of the total $\mathrm{N}$ was observed from June 22 to July 16, and the highest peak of the total $P$ was observed on August $12($ at $7 \mathrm{pm})$ for rice-field drainage and on October 22 (at 7 am) for adjacent stream water, respectively.

\section{Nutrient runoff loss loadings from the rice plantation area}

The results of the total $\mathrm{N}$ and $\mathrm{P}$ loss loadings from the rice plantation area are given in Fig. 4. The annual average $\mathrm{N}$ and $\mathrm{P}$ runoff from paddy field were $11.6 \mathrm{~kg} \mathrm{ha}^{-1}$ and $1.5 \mathrm{~kg} \mathrm{ha}^{-1}$, respectively. At each runoff event, most of the $\mathrm{N}$ loss loading throughout the year was lower than $400 \mathrm{~g} \mathrm{ha}^{-1}$. However, it increased 
sharply, i.e., reaching $1685.7 \mathrm{~g} \mathrm{ha}^{-1}$ from June 17 to September 4. The total P loss loading fluctuated greatly throughout the year, with $73.0 \%$ of the values lower than $20 \mathrm{~g} \mathrm{ha}^{-1}$ and $14.9 \%$ of the values higher than $40 \mathrm{~g} \mathrm{ha}^{-1}$, respectively. The total $\mathrm{N}$ and $\mathrm{P}$ runoff loss exhibited significant linear relationships with the runoff amount (Fig. 5, $p<0.001$ ). The total $\mathrm{N}$ and $\mathrm{P}$ can be predicted with the runoff amount following the equations: $R^{2}=0.54$ and $R^{2}=0.88$, respectively.

\section{Abstract visualization and prediction of nutrient runoff loss by SOM approach}

The abstract visualization of the relationships between the total $\mathrm{N}$ and $\mathrm{P}$ concentrations in the retention ditch and adjacent stream water samples as well as the SOM-obtained accumulated rainfall amounts at 6-48 $\mathrm{h}$ intervals (i.e., $\mathrm{H6}-\mathrm{H} 48$ ) before each water sampling event, is shown in Fig. 6. The results suggest that the high total $\mathrm{P}$ concentration in the rice-field drainage $\left(0.28 \mu \mathrm{g} \mathrm{L}^{-1}\right)$ was a response to the low rainfall amounts at $\mathrm{H} 6(3.59 \mathrm{~mm}), \mathrm{H} 12(6.02 \mathrm{~mm}), \mathrm{H} 18(7.81 \mathrm{~mm}), \mathrm{H} 24(9.18 \mathrm{~mm}), \mathrm{H} 36(11.2 \mathrm{~mm})$, and $\mathrm{H} 48(12.4 \mathrm{~mm})$ (Figure 6). Meanwhile, the high total $\mathrm{N}$ concentration in the rice-field drainage $(>2.5 \mu \mathrm{g}$ $\left.\mathrm{L}^{-1}\right)$ was a response to the low rainfall amounts at $\mathrm{H} 6(<3.07 \mathrm{~mm}), \mathrm{H} 12(<5.34 \mathrm{~mm}), \mathrm{H} 18(<7.59 \mathrm{~mm})$, $\mathrm{H} 24$ (< $9.19 \mathrm{~mm}), \mathrm{H} 36$ (< $11.0 \mathrm{~mm})$, and H48 (< $12.2 \mathrm{~mm}$ ) (Figure 6).

\section{Discussion}

We found that the window phase for the total $\mathrm{N}$ loss mainly appeared in the rice-growing season. However, the window phase for the total $\mathrm{P}$ loss was more dispersive, attributed to the different behavior of the total $\mathrm{N}$ and $\mathrm{P}$ in the runoff and the fertilizer management during the planting of rice. The demand for $\mathrm{N}$ in rice is much higher than that of $\mathrm{P}$. In this experiment, $\mathrm{N}$ fertilizer (i.e., $186 \mathrm{~kg} \mathrm{~N} \mathrm{ha}^{-1}$ ) was applied to the soil on three occasions, mainly in July-August. However, $\mathrm{P}$ fertilizer (i.e., $120 \mathrm{~kg} \mathrm{P}_{2} \mathrm{O}_{5} \mathrm{ha}^{-1}$ ) was applied as a base fertilizer before rice planting.

Additionally, studies show that soil P has a much lower migration rate than soil $\mathrm{N}$ [38]. Some studies [3941] confirm that $\mathrm{N}$ losses with both forms, i.e., organic nitrogen (Org- $\mathrm{N})$ and nitrate $\left(\mathrm{NO}_{3}-\mathrm{N}\right)$, are predominantly conditioned by the soil fertilization type, while $\mathrm{P}$ losses are mainly associated with soil particles, and the agricultural land uses at any intensity. Therefore, the window phase of total $\mathrm{N}$ is mainly concentrated in the rice-planting season following fertilization. Contrarily, the window phase of total P is relatively dispersed throughout the year, attributed to the surface runoff. The study showed that the peak flows in the window phase usually contained the majority of $\mathrm{N}$ and $\mathrm{P}$ loss $[42,43]$.

Meanwhile, the loss window phases of total $\mathrm{N}$ and $\mathrm{P}$ are consistent with the runoff pattern. When runoff occurs, higher total P loss loading also occurs (Fig. 4). However, the concentration does not show the same pattern. The concentration of total $P$ in the runoff during heavy rainfall periods (especially in the rice-planting season from June to July) is rather low. The low total P concentration may be due to the strong effect of $P$ immobilization and the adsorption onto the soil [44]. Some studies [45] show that the total $\mathrm{P}$ in the paddy soil is mainly organic $\mathrm{P}$ and inorganic $\mathrm{Al}$ oxide- $\mathrm{P}$ and Fe oxide-P, which is wrapped in aggregates, and it is not easily released into the runoff. Some studies $[46,47]$ showed that $P$ migrates 
mainly through small-sized organic-inorganic composite colloids. Therefore, its mobility is relatively less affected by runoff, and its concentration increases when soluble $P$ and colloidal $P$ enter the water body with an increasing runoff amount. During heavy rainfall, all the soluble $P$ and colloidal $P$ in the soils carried by the runoff, and the concentration is diluted, resulting in a lower concentration [47]. However, owing to the fertilization that occurs during the rice-planting period, the $\mathrm{N}$ concentration in the soil tends to be remarkably high, with a peak value consistent with the peak value of the heavy rainfall.

Moreover, the results of their study revealed that the total $\mathrm{N}$ and $\mathrm{P}$ concentrations in irrigation water have an impact on the drainage total $\mathrm{N}$ and $\mathrm{P}$ loads. However, the total $\mathrm{N}$ and $\mathrm{P}$ transport to the tile-drains was primarily regulated by the macropore flow and was not significantly affected by storms [4]. Furthermore, a study by van der Salm et al. [48] on the nutrient losses from a heavy clay soil in a fluvial plain in the Netherlands found that the contribution of pipe drains to the total discharge of $\mathrm{N}$ and $\mathrm{P}$ was strongly related to the length of the dry period in the preceding summer, attributed to the very low conductivity of the soil matrix and the formation of shrinkage cracks. Another study [49] reports that the total $P$ concentration in the drainage flow is independent of the Olsen $\mathrm{P}$, while the antecedent soil moisture had a strong influence on the total $\mathrm{P}$ loss in the drainage flow. Furthermore, higher concentrations were recorded above a certain soil moisture deficit threshold.

The $\Delta$ total $\mathrm{N}$, in this study, showed negative values, while the $\Delta$ total $\mathrm{P}$ showed positive values. This finding indicates the role of the stream on total $\mathrm{N}$ and $\mathrm{P}$ at different periods. The field runoff or channel drainage often influences the stream water quality. A study by Tomer et al. [50] on runoff in the Tipton Creek watershed (lowa) shows that the channel drainage dominated, and was an essential source of the total $\mathrm{N}$ and $\mathrm{P}$ discharge of the watershed. In the present study, total $\mathrm{P}$ concentrations were high in the water samples, especially in the water sample from the retention ditch. More than $75 \%$ of the drainage water samples had higher P concentrations than that stated in the United States Environmental Protection Agency (US EPA) guidelines (i.e., $0.10 \mathrm{mg}$ total $\mathrm{P} \mathrm{L}^{-1}$ for streams) [51], and more than $90 \%$ of the samples exceeded $0.02 \mathrm{mg}$ total $\mathrm{PL}^{-1}$. This value is a critical total $\mathrm{P}$ concentration value, above which the eutrophication in the surface water would accelerate [52]. These data indicate that the water monitoring and forecasting of the retention ditch are essential to protect the water quality of the adjacent streams.

The annual average $\mathrm{N}$ runoff from the paddy field was $11.6 \mathrm{~kg} \mathrm{ha}^{-1}$, which is consistent with the average loss loading of $12.7 \mathrm{~kg} \mathrm{ha}^{-1}$ confirmed by field-scale experiments $[8,53,54]$. The annual average $P$ runoff from the paddy field was $1.5 \mathrm{~kg} \mathrm{ha}^{-1}$, which was higher than the $0.75 \mathrm{~kg} \mathrm{ha}^{-1}$ of total $P$ by field-scale experiments in TaiHu region of China $[17,55]$. Other field-scale studies $[12,18]$ found a higher P runoff, which ranged from 5.49 to $17.68 \mathrm{~kg} \mathrm{ha}^{-1}$. We also found that the total $\mathrm{N}$ and $\mathrm{P}$ loss loadings, rather than the concentrations of total $\mathrm{N}$ and $\mathrm{P}$ in the runoff, were linearly related to the surface runoff amount, which confirmed our hypothesis. This result shows that we can predict the loss loadings of total $\mathrm{N}$ and $\mathrm{P}$ using the cumulative runoff amount. As the total $\mathrm{N}$ and $\mathrm{P}$ concentrations fluctuate across the rice seasons, the total $\mathrm{N}$ and $\mathrm{P}$ loss loadings cannot be directly calculated as the product of the concentration and runoff 
at each time point. This relationship provides a simple tool for predicting the nutrient loss loading in the retention ditches of the paddy field. Consistent with our results, a study by Xue et al. [56] in the Baltic Region also shows no correlations between the nutrient concentrations and precipitation in the Mrzezino canal. Meanwhile, other studies [43] indicate the similarities in total P loss in the tile drainage and surface runoff, as well as the strong correlations between total P loss and storm hydrographs.

Using high-resolution monitoring at 6-h intervals, we found that the rainfall amount was an essential factor that affects the total $\mathrm{N}$ and $\mathrm{P}$ concentrations in the retention ditch. These findings are supported by the results of other studies that were conducted in eastern China and other Asian monsoon areas $[57,58]$. However, the SOM showed weak relationships between the rainfall at $6,12,18,24,36$, and $48 \mathrm{~h}$ intervals with the total $\mathrm{N}$ and $\mathrm{P}$ concentrations. Some studies using high temporal resolution monitoring (i.e., at 0.5 $\mathrm{h}$ intervals) show that using a one-hour sampling frequency may lead to a higher error in assessing the total pollution load than when using $0.5 \mathrm{~h}$ frequency [59]. However, determining whether this error is an over- or under-estimation depends on which one-hour sample set was used. This is also consistent with our result, which revealed that using more than $24 \mathrm{~h}$ monitoring data did not improve the relationship between the total $\mathrm{N}$ and $\mathrm{P}$ in the retention ditch and the accumulated rainfall amount than when using shorter monitoring periods, i.e., $<24 \mathrm{~h}$.

In addition to the rainfall, there are many other factors, such as soil conditions (i.e., soil moisture, soil depth, soil macropore, available $\mathrm{N}$ and Olsen $\mathrm{P}$ concentrations) and management practices (i.e., irrigation $\mathrm{N}$ and $\mathrm{P}$ concentrations, dry period, land cover, and fertilization), that influence the drainage water $\mathrm{N}$ and $P$ concentrations or loadings $[4,47,60]$. Therefore, future studies should consider such additional environmental and management factors in the SOM approach to improve prediction accuracy. The SOM approach, developed in this study, helps to predict the total $\mathrm{N}$ and $\mathrm{P}$ in the drainage based on highresolution monitoring data, i.e., at 6-h intervals. This approach was easy to implement by river managers in designing a long-term protection plan to maintain the water quality; however, it may be unable to predict the daily total $\mathrm{N}$ and $\mathrm{P}$ concentrations based on the daily rainfall forecast. In the present study, we only investigated the total $\mathrm{P}$ and $\mathrm{N}$ in the drainage water. Other $\mathrm{P}$ and $\mathrm{N}$ forms, especially particulate, colloid, soluble, reactive, and unreactive $\mathrm{P}, \mathrm{NH}_{3}{ }^{+}-\mathrm{N}$, and $\mathrm{NO}_{3}{ }^{-} \mathrm{N}$ should be tested further because several studies have shown that their response to rainfall in storm events was much closer than that of the total $\mathrm{P}[4]$.

\section{Conclusions}

We found some significant window phases and dissipation periods for the runoff of total $\mathrm{N}$ and $\mathrm{P}$ in the large-scale observation system of the paddy field. However, the total $\mathrm{N}$ and $\mathrm{P}$ showed different patterns. Using high-resolution monitoring data at 6-h intervals, we found that there is a strong relationship between the runoff and total $\mathrm{N}$ and $\mathrm{P}$ losses from the paddy field. The high-resolution monitoring data enabled the establishment of the relationship between the rainfall and total $\mathrm{N}$ and $\mathrm{P}$ concentrations in the runoff; thus, it can be used to predict the daily total $\mathrm{N}$ and $\mathrm{P}$ loss potential and guide agricultural non- 
point source pollution control practices in the future. Future studies should incorporate other factors such as soil conditions and agricultural practices into the SOM approach for improving prediction accuracy.

\section{Declarations}

\section{Ethics approval and consent to participate}

Not applicable.

\section{Consent for publication}

Not applicable.

\section{Availability of data and material}

The datasets used and/or analyzed during the current study are available from the corresponding author on reasonable request.

\section{Competing interests}

The authors declare no competing interests.

\section{Funding}

This study was financially supported by the Major Science and Technology Program for water pollution control and treatment (2018ZX07208009), the National Natural Science Foundation of China (41671300), and the National Key Research and Development Program of China (2017YFD0800103).

\section{Author Contributions}

SH and FYL are the co-first authors of this article, $X Q L$ is the corresponding author, $S H, S W, Y B J, B Y L$, GMT and FYL designed this study and conducted data analysis, and XQL and HL provided financial support in the form of this project. SH and FYL wrote the manuscript and had the primary responsibility for the final content. All authors read and approved the final manuscript.

\section{Acknowledgements}

We highly appreciate the anonymous reviewers and the handling editor for their helpful comments improving the quality and clarity of this work. We also appreciate grants from Major Science and Technology Program for water pollution control and treatment (2018ZX07208009), the National Natural Science Foundation of China $(41522108 ; 41671300)$, and the National Key Research and Development Program of China (2017YFD0800103).

\section{Abbreviations}


SOM: self-organizing maps; N: nitrogen; P: phosphorus; MASE: mean absolute scaled errors; Rd: runoff amount; Rf: rainfall; PP: particulate P

\section{References}

1. Frey SK, Topp E, Ball BR, Edwards M, Gottschall N, Sunohara M, Zoski E, Lapen DR (2013) Tile drainage management influences on surface-water and groundwater quality following liquid manure application. J Environ Qual 42:881-92. https://doi.org/10.2134/jeq2012.0261.

2. Liang XQ, Chen YX, Nie ZY, Ye YS, Liu J, Tian GM, Wang GH, Tuong TP (2013) Mitigation of nutrient losses via surface runoff from rice cropping systems with alternate wetting and drying irrigation and site-specific nutrient management practices. Environ Sci Pollut Res 20:6980-6991. https://doi.org/10.1007/s11356-012-1391-1.

3. McDowell RW, Snelder T, Littlejohn R, Hickey M, Cox N, Booker DJ (2011) State and potential management to improve water quality in an agricultural catchment relative to a natural baseline. Agric Ecosyst Environ 144:188-200. https://doi.org/10.1016/j.agee.2011.07.009.

4. Vidon P, Cuadra PE (2011) Phosphorus dynamics in tile-drain flow during storms in the US Midwest. Agric Water Manag 98:532-540. https://doi.org/10.1016/j.agwat.2010.09.010.

5. Iwasaki Y, Nakamura K, Kawashima S, Horino H (2014) Assessment of factors influencing groundwater-level change using groundwater flow simulation, considering vertical infiltration from rice-planted and crop-rotated paddy fields in Japan. Hydrogeol J 22:1841-1855. https://doi.org/10.1007/s10040-014-1171-8.

6. Liu X, Wang H, Zhou J, Chen Z, Lu D, Zhu D, Deng P (2017) Effect of nitrogen root zone fertilization on rice yield, uptake and utilization of macronutrient in lower reaches of Yangtze River, China. Paddy Water Environ 15:625-638. https://doi.org/10.1007/s10333-017-0581-3.

7. Jiang X, Amelung W, Cade-Menun BJ, Bol R, Willbold S, Cao Z, Klumpp E (2017) Soil organic phosphorus transformations during 2000 years of paddy-rice and non-paddy management in the Yangtze River Delta, China. Sci Rep 7:10818. https://doi.org/10.1038/s41598-017-10071-0.

8. Zhang Y, Liu H, Guo Z, Zhang C, Sheng J, Chen L, Luo Y, Zheng J (2018) Direct-seeded rice increases nitrogen runoff losses in southeastern China. Agric Ecosyst Environ 251:149-157. https://doi.org/10.1016/j.agee.2017.09.022.

9. Liang XQ, Harter T, Porta L, van Kessel C, Linquist BA (2014) Nitrate leaching in Californian rice fields: A field- and regional-scale assessment. J Environ Qual 43:881-894. https://doi.org/10.2134/jeq2013.10.0402.

10. Wang S, Liang X, Chen Y, Luo Q, Liang W, Li S, Huang C, Li Z, Wan L, Li W, Shao X (2012) Phosphorus loss potential and phosphatase activity under phosphorus fertilization in long-term paddy wetland agroecosystems. Soil Sci Soc Am J 76:161-167. https://doi.org/10.2136/sssaj2011.0078.

11. Suriyagoda L, Sirisena D, Kekulandara D, Bandaranayake P, Samarasinghe G, Wissuwa M (2020) Biomass and nutrient accumulation rates of rice cultivars differing in their growth duration when 
grown in fertile and low-fertile soils. J Plant Nutr 43:251-269.

https://doi.org/10.1080/01904167.2019.1676903.

12. Zhang ZJ, Zhang JY, He R, Wang ZD, Zhu YM (2007). Phosphorus interception in floodwater of paddy field during the rice-growing season in Taihu lake basin. Environ Pollut 145:425-433. https://doi.org/10.1016/j.envpol.2006.05.031.

13. Wang K, Zhang Z, Zhu Y, Wang G, Shi D, Christie P (2001) Surface water phosphorus dynamics in rice fields receiving fertiliser and manure phosphorus. Chemosphere 42:209-214. https://doi.org/10.1016/S0045-6535(00)00127-2.

14. Zhou W, Guo Z, Chen J, Jiang J, Hui D, Wang X, Sheng J, Chen L, Luo Y, Zheng J, Li S, Zhang Y (2019) Direct seeding for rice production increased soil erosion and phosphorus runoff losses in subtropical China. Sci Total Environ 695:133845. https://doi.org/10.1016/j.scitotenv.2019.133845.

15. Linquist BA, Ruark MD, Mutters R, Greer C, Hill JE (2014) Nutrients and sediments in surface runoff water from direct-seeded rice fields: Implications for nutrient budgets and water quality. J Environ Qual 43:1725-1735. https://doi.org/10.2134/jeq2014.03.0135.

16. Poudel DD, Lee T, Srinivasan R, Abbaspour K, Jeong CY (2013) Assessment of seasonal and spatial variation of surface water quality, identification of factors associated with water quality variability, and the modeling of critical nonpoint source pollution areas in an agricultural watershed. J Soil Water Conserv 68:155-171. https://doi.org/10.2489/jswc.68.3.155.

17. Guo HY, Zhu JG, Wang XR, Wu ZH, Zhang Z (2004) Case study on nitrogen and phosphorus emissions from paddy field in Taihu region. Environ Geochem Health 26:209-219. https://doi.org/10.1023/B:EGAH.0000039583.71423.b4.

18. Zhang Z, Zhu Y, Cheng J, Bailey JS (2002) Phosphorus export from a paddy rice field during flood events. Soil Use Manag 18:316-323. https://doi.org/10.1079/sum2002137.

19. Liang XQ, Li L, Chen YX, Li H, Liu J, He MM, Ye YS, Tian GM, Lundy M (2013) Dissolved phosphorus losses by lateral seepage from swine manure amendments for organic rice production. Soil Sci Soc Am J 77:765-773. https://doi.org/10.2136/sssaj2012.0345.

20. Chen D, Hu M, Wang J, Guo Y, Dahlgren RA (2016) Factors controlling phosphorus export from agricultural/forest and residential systems to rivers in eastern China, 1980-2011. J Hydrol 533:5361. https://doi.org/10.1016/j.jhydrol.2015.11.043.

21. Ramos TB, Gonçalves MC, Branco MA, Brito D, Rodrigues S, Sánchez-Pérez J-M Sauvage S, Prazeres A, Martins JC, Fernandes ML, Pires FP (2015) Sediment and nutrient dynamics during storm events in the Enxoé temporary river, southern Portugal. Catena 127:177-190.

https://doi.org/10.1016/j.catena.2015.01.001.

22. Heathman GC, Sharpley AN, Smith SJ, Robinson JS (1994) Land application of poultry litter and water quality in Oklahoma, U.S.A. Fertil Res 40:165-173. https://doi.org/10.1007/BF00750462.

23. Sharpley AN (1997) Rainfall frequency and nitrogen and phosphorus runoff from soil amended with poultry litter. J Environ Qual 26:1127-1132.

https://doi.org/10.2134/jeq1997.00472425002600040026x.

Page 12/21 
24. Liu M, Lu J (2014) Support vector machine-an alternative to artificial neuron network for water quality forecasting in an agricultural nonpoint source polluted river? Environ Sci Pollut Res 21:11036-11053. https://doi.org/10.1007/s11356-014-3046-x.

25. Zheng ZM, Zhang TQ, Kessel C, Tan CS, O'Halloran IP, Wang YT, Speranzini D, Van Eerd LL (2015) Approximating phosphorus leaching from agricultural organic soils by soil testing. J Environ Qual 44:1871-1882. https://doi.org/10.2134/jeq2015.05.0211.

26. Chen D, Lu J, Shen Y (2010) Artificial neural network modelling of concentrations of nitrogen, phosphorus and dissolved oxygen in anon-point source polluted river in Zhejiang Province, southeast China. Hydrol Process 24:290-299. https://doi.org/10.1002/hyp.7482.

27. Young EO, Geibel JR, Ros DS (2017) Influence of controlled drainage and liquid dairy manure application on phosphorus leaching from intact soil cores. J Environ Qual 46:80-87. https://doi.org/10.2134/jeq2016.04.0158.

28. Lamba J, Srivastava P, Way TR, Sen S, Wood CW, Yoo KH (2013) Nutrient loss in leachate and surface runoff from surface-broadcast and subsurface-banded broiler litter. J Environ Qual 42:15741582. https://doi.org/10.2134/jeq2013.02.0064.

29. Ulén B, Geranmayeh P, Blomberg M, Bieroza M (2019) Seasonal variation in nutrient retention in a free water surface constructed wetland monitored with flow-proportional sampling and optical sensors. Ecol Eng 139:105588. https://doi.org/10.1016/j.ecoleng.2019.105588.

30. Koskiaho J, Puustinen M (2019) Suspended solids and nutrient retention in two constructed wetlands as determined from continuous data recorded with sensors. Ecol Eng 135:65-75. https://doi.org/10.1016/j.ecoleng.2019.04.006.

31. APHA (American Public Health Association) (1995) Standard methods for the examination of water and wastewater. 19th ed. Washington, DC.

32. Liang XQ, Zhou KJ, Wang XQ (2019) Process and simulation of surface source pollution in rice field. First edition, Science Press, Beijing.

33. Lee BH, Scholz M (2006) Application of the self-organizing map (SOM) to assess the heavy metal removal performance in experimental constructed wetlands. Water Res 40:3367-3374. https://doi.org/10.1016/j.watres.2006.07.027.

34. Liang X, Zhu S, Ye R, Guo R, Zhu C, Fu C, Tian G, Chen Y (2014) Biological thresholds of nitrogen and phosphorus in a typical urban river system of the Yangtz delta, China. Environ Pollut 192:251-258. https://doi.org/10.1016/j.envpol.2014.04.007.

35. Zelazny M, Astel A, Wolanin A, Małek S (2011) Spatiotemporal dynamics of spring and stream water chemistry in a high-mountain area. Environ Pollut 159:1048-1057. https://doi.org/10.1016/j.envpol.2010.11.021.

36. Polanco X, François C, Lamirel JC (2001) Using artificial neural networks for mapping of science and technology: A multi-self-organizing-maps approach. Scientometrics 51:267-292. https://doi.org/10.1023/A:1010537316758. 
37. Zhang L, Scholz M, Mustafa A, Harrington R (2008) Assessment of the nutrient removal performance in integrated constructed wetlands with the self-organizing map. Water Res 42:3519-3527. https://doi.org/10.1016/j.watres.2008.04.027.

38. Wu L. (1996) Study on rainfall process, flow-making and nitrogen and phosphorus losses. J Environ Sci 16:111-116. https://doi.org/10.13671/j.hjkxxb.1996. 01.015.

39. Ramos MC, Lizaga I, Gaspar L, Quijano L, Navas A (2019) Effects of rainfall intensity and slope on sediment, nitrogen and phosphorous losses in soils with different use and soil hydrological properties. Agric Manage Water 226:105789. https://doi.org/10.1016/j.agwat.2019.105789.

40. Ramos MC, Benito C, Martínez-Casasnovas JA (2015) Simulating soil conservation measures to control soil and nutrient losses in a small, vineyard dominated, basin. Agric, Ecosys Environ 213:194-208. https://doi.org/10.1016/j.agee.2015.08.004.

41. Daverede IC, Kravchenko AN, Hoeft RG, Nafziger ED, Bullock DG, Warren JJ, Gonzini LC (2003) Phosphorus runoff: effect of tillage and soil phosphorus levels. J Environ Qual 32:1436-1444. https://doi.org/10.2134/jeq2003.1436.

42. Smith DR, King KW, Johnson L, Francesconi W, Richards P, Baker D, Sharpley AN (2015) Surface runoff and tile drainage transport of phosphorus in the midwestern United States. J Environ Qual 44:495-502. https://doi.org/10.2134/jeq2014.04.0176.

43. King KW, Williams MR, Fausey NR (2015) Contributions of systematic tile drainage to watershedscale phosphorus transport. J Environ Qual 44:486-494. https://doi.org/10.2134/jeq2014.04.0149.

44. Li F, Liang X, Zhang H, Tian G (2019) The influence of no-till coupled with straw return on soil phosphorus speciation in a two-year rice-fallow practice. Soil Tillage Res 195:104389. https://doi.org/10.1016/j.still.2019.104389.

45. Heathwaite L, Haygarth P, Matthews R, Preedy N, Butler P (2005) Evaluating colloidal phosphorus delivery to surface waters from diffuse agricultural sources. J Environ Qual 34:287-298. https://doi.org/10.2134/jeq2005.0287.

46. Liang X, Jin Y, Zhao Y, Wang Z, Yin R, Tian G (2016) Release and migration of colloidal phosphorus from a typical agricultural field under long-term phosphorus fertilization in southeastern China. $J$ Soils Sediments 16:842-853. https://doi.org/10.1007/s11368-015-1290-4.

47. Lang TA, Oladeji O, Josan M, Daroub S (2010) Environmental and management factors that influence drainage water $\mathrm{P}$ loads from Everglades Agricultural Area farms of South Florida. Agric Ecosyst Environ 138:170-180. https://doi.org/10.1016/j.agee.2010.04.015.

48. van der Salm C, van den Toorn A, Chardon WJ, Koopmans GF (2012) Water and nutrient transport on a heavy clay soil in a fluvial plain in the Netherlands. J Environ Qual 41:229-241. https://doi.org/10.2134/jeq2011.0292.

49. Cassidy R, Doody DG, Watson CJ (2017) Impact of legacy soil phosphorus on losses in drainage and overland flow from grazed grassland soils. Sci Total Environ 575:474-484. https://doi.org/10.1016/j.scitotenv.2016.07.063. 
50. Tomer MD, Wilson CG, Moorman TB, Cole KJ, Heer D, Isenhart TM (2010) Source-pathway separation of multiple contaminants during a rainfall-runoff event in an artificially drained agricultural watershed. J Environ Qual 39:882-895. https://doi.org/10.2134/jeq2009.0289.

51. Sharpley A, Daniel TC, Sims JT, Pote DH (1996) Determining environmentally sound soil phosphorus levels. J Soil Water Conserv 51:160-166. http://dx.doi.org/51:160-166. 10.1016/00167061(95)00072-0.

52. Vollenweider RA (1976) Advances in defining critical loading levels for phosphorus in lake eutrophication. Mem Ist Ital Idrobiol 33:53-83.

53. Chen G, Chen Y, Zhao G, Cheng W, Guo S, Zhang H, Shi W (2015) Do high nitrogen use efficiency rice cultivars reduce nitrogen losses from paddy fields? Agric, Ecosyst Environ 209:26-33. http://dx.doi.org/10.1016/j.agee.2015.03.003.

54. Xue L, Yu Y, Yang L (2014) Maintaining yields and reducing nitrogen loss in rice-wheat rotation system in Taihu Lake region with proper fertilizer management. Environ Res Lett 9:115010-115020. http://dx.doi.org/10.1088/1748-9326/9/11/115010.

55. Zhang Z, Zhu Y, Guo P, Liu G (2004) Potential loss of phosphorus from a Rice Field in Taihu Lake Basin. J Environ Qual 33:1403-1412. https://doi.org/10.2134/jeq2004.1403.

56. Wojciechowska E, Pietrzak S, Matejłukowicz K, Nawrot N, Zima P, Kalinowska D, Wielgat P, ObarskaPempkowiak H, Gajewska M, Dembska G, Jasinski, Pazikowska-Sapota G, Galer-Tatarowicz K, Dzierzbicka-Glowacka L (2019) Nutrient loss from three small-size watersheds in the southern Baltic Sea in relation to agricultural practices and policy. J Environ Manage 252:109637. https://doi.org/10.1016/j.jenvman.2019.109637.

57. Liu J, Zuo Q, Zhai LM, Luo CY, Liu HB, Wang HY, Liu S, Zou GY, Ren TZ (2016) Phosphorus losses via surface runoff in rice-wheat cropping systems as impacted by rainfall regimes and fertilizer applications. J Integr Agric 15:667-677 https://doi.org/10.1016/S2095-3119(15)61087-5.

58. Jung JW, Lim SS, Kwak JH, Park HJ, Yoon KS, Kim HY, Baek WJ, Choi WJ (2015) Further understanding of the impacts of rainfall and agricultural management practices on nutrient loss from rice paddies in a monsoon area. Water Air Soil Pollut 226:283. https://doi.org/10.1007/s11270015-2551-y.

59. Granger SJ, Hawkins JMB, Bol R, White SM, Naden P, Old G, Bilotta GS, Brazier RE, Macleod CJA, Haygarth PM (2010) High temporal resolution monitoring of multiple pollutant responses in drainage from an intensively managed grassland catchment caused by a summer storm. Water Air Soil Pollut 205:377-393. https://doi.org/10.1007/s11270-009-0083-z.

60. Wang Y, Li H, Xu Z (2016) Rainfall-induced nutrient losses from manure-fertilized farmland in an alluvial plain. Environ Monit Assess 188:1-11. https://doi.org/10.1007/s10661-015-5008-2.

\section{Table}


Table 1 Total $\mathrm{N}$ and $\mathrm{P}$ of rice-field drainage in retention ditch and adjacent stream water samples and the accumulated rainfall amount during the 6-48 hours before the water samples were taken $(\mathrm{n}=977)$.

\begin{tabular}{lcccccc}
\hline & \multicolumn{3}{c}{ Total N $\left(\mathrm{mg} \mathrm{L}^{-1}\right)$} & \multicolumn{3}{c}{ Total P $\left(\mathrm{mg} \mathrm{L}^{-1}\right)$} \\
\hline & Ditch & Stream & $\Delta$ D-S§ & Ditch & Stream & $\Delta$ D-S§ \\
\hline Mean & 2.11 & 2.36 & -0.25 & 0.24 & 0.18 & 0.06 \\
\hline Median & 1.70 & 2.21 & -0.51 & 0.22 & 0.17 & 0.03 \\
\hline Minimum & 0.31 & 0.48 & -0.17 & 0.01 & 0.00 & -0.86 \\
\hline Maximum & 7.89 & 5.57 & 2.32 & 1.18 & 1.13 & 1.04 \\
\hline 25\% percentile & 1.14 & 1.56 & -0.42 & 0.15 & 0.12 & -0.01 \\
& & & & & & \\
\hline 75\% percentile & 2.77 & 3.07 & -0.30 & 0.28 & 0.22 & 0.08 \\
& & & & & & \\
\hline
\end{tabular}

$\S$ Total $\mathrm{N}$ and $\mathrm{P}$ in retention ditch water minus that in the adjacent stream

\section{Figures}
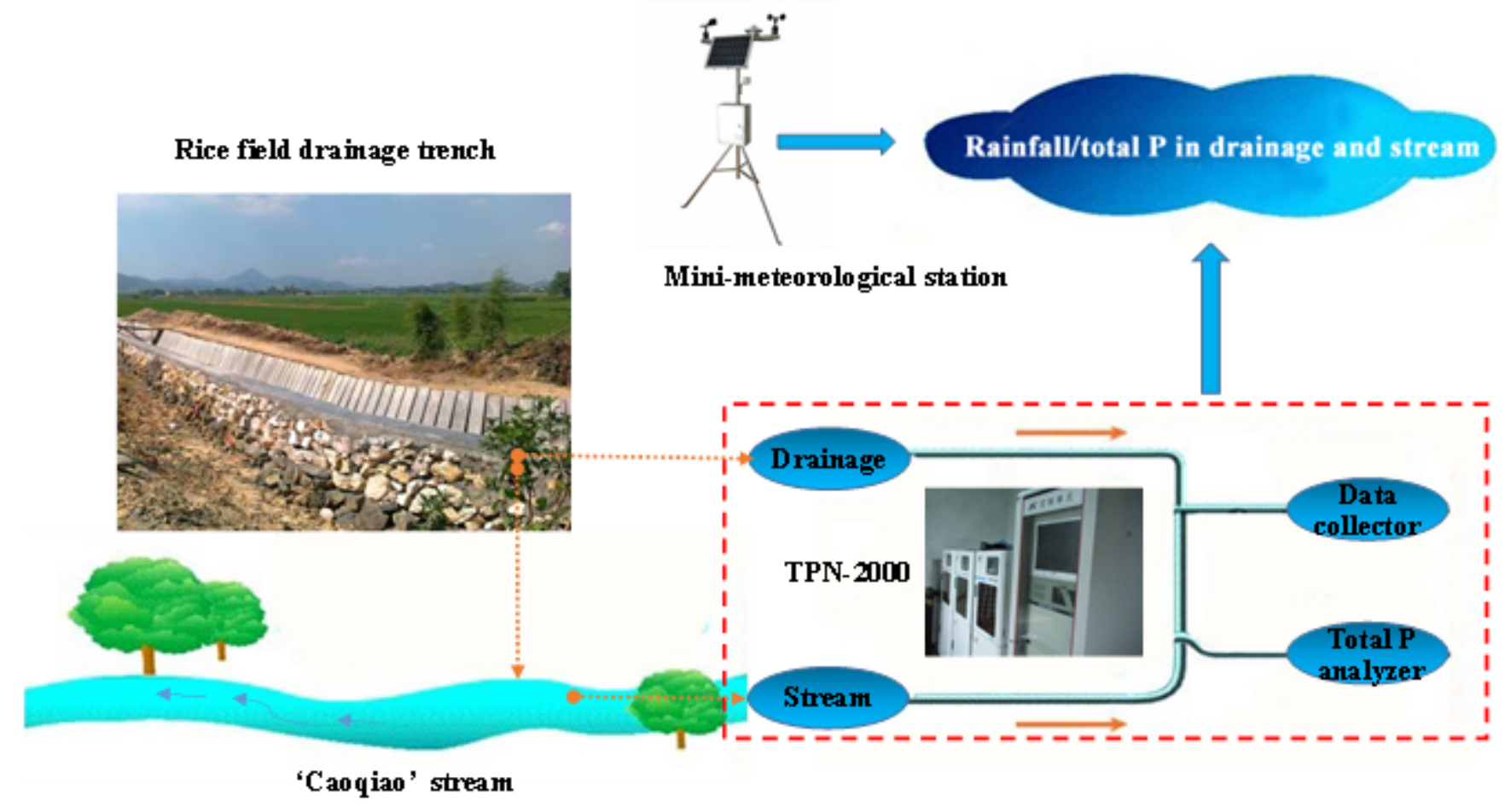

Mini-meteorological station 
Figure 1

Diagram of high-resolution monitoring of rainfall amount and total $\mathrm{N}$ and $\mathrm{P}$ concentrations in runoff and adjacent stream water samples.

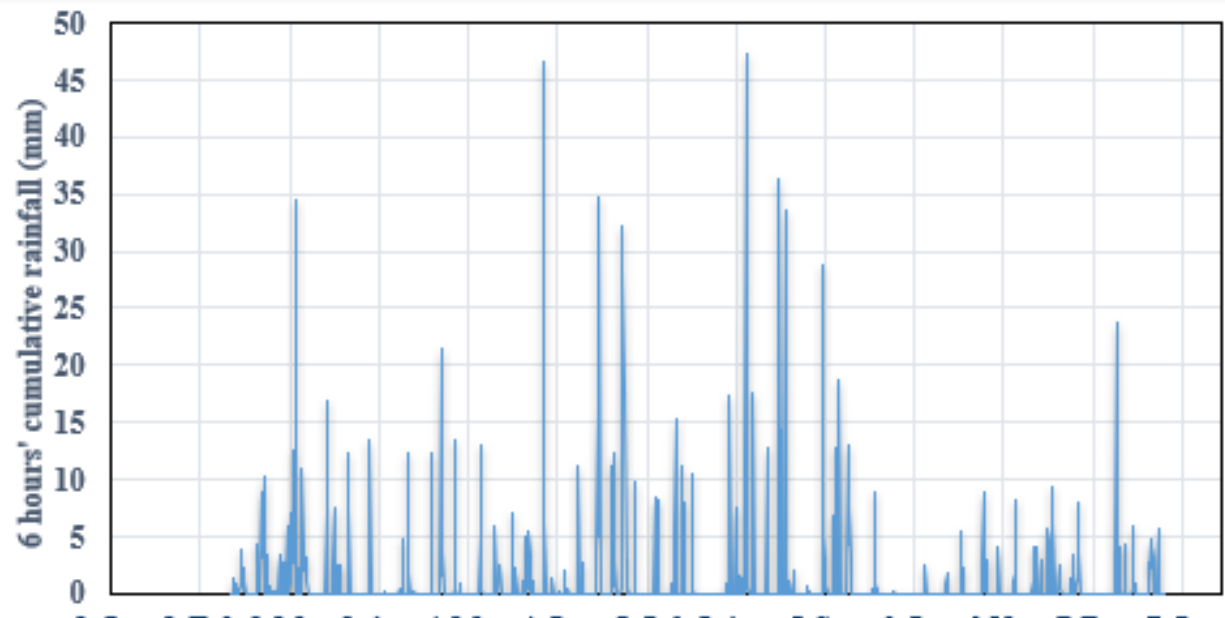

1-Jan 1-Feb 3-Mar 3-Apr 4-May 4-Jun 5-Jul 5-Aug 5-Sep 6-Oct 6-Nov 7-Dec 7-Jan

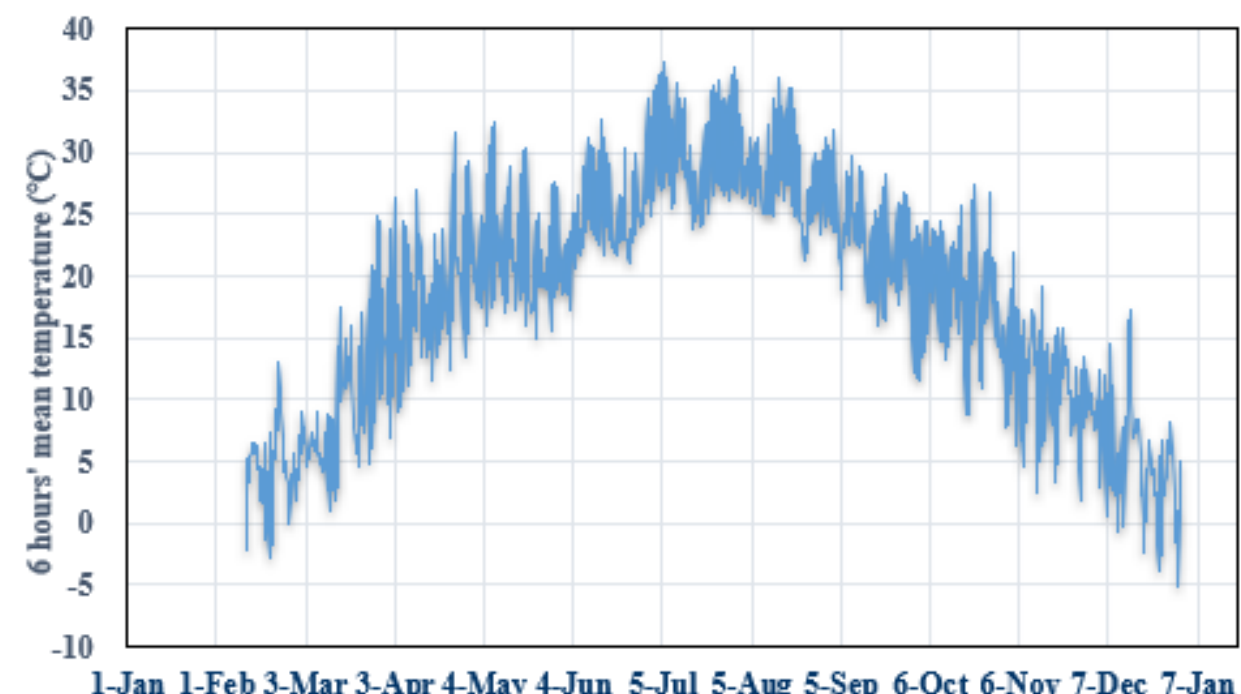

\section{Figure 2}

Six-hour cumulative rainfall and mean temperature during the observation period. 

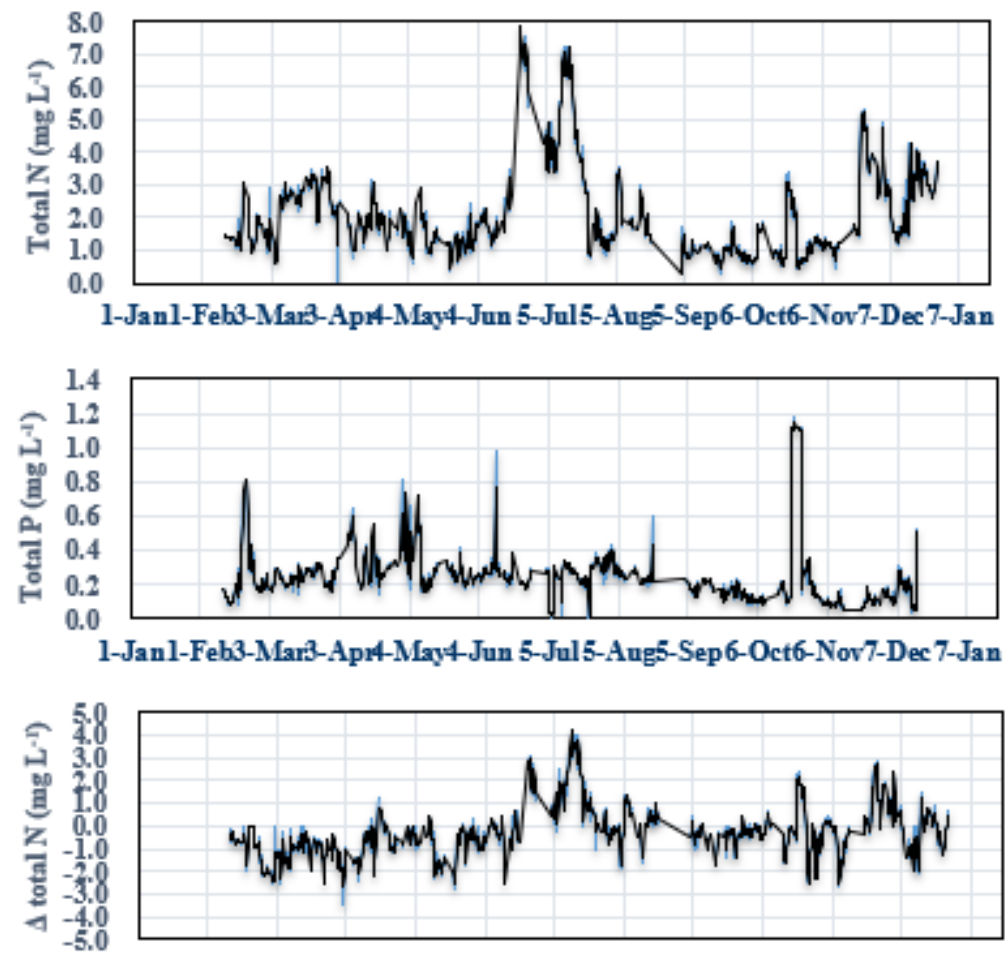

1-Janl-Feb3-Mar3-Ap4-May4-Jun 5-Jul5-Aug5-Sep6-Oct6-Nov7-Dec 7-Jan

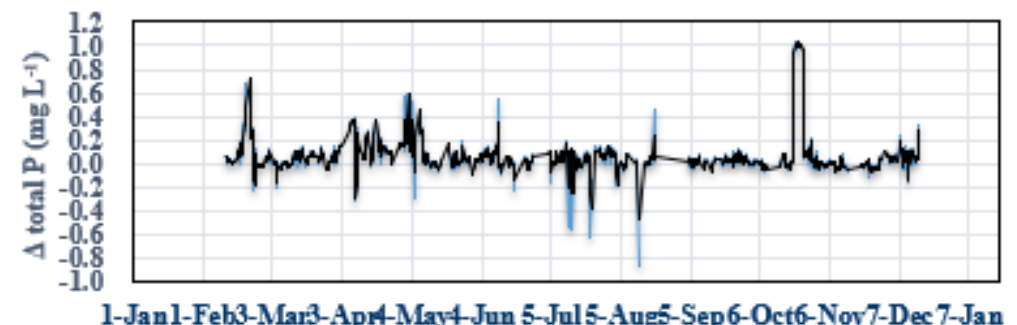

Figure 3

Temporal changes in nutrient concentrations (total $\mathrm{N}$ and $\mathrm{P}$ ) in runoff in the rice-planting area and difference in nutrient concentrations between runoff and adjacent stream water. 


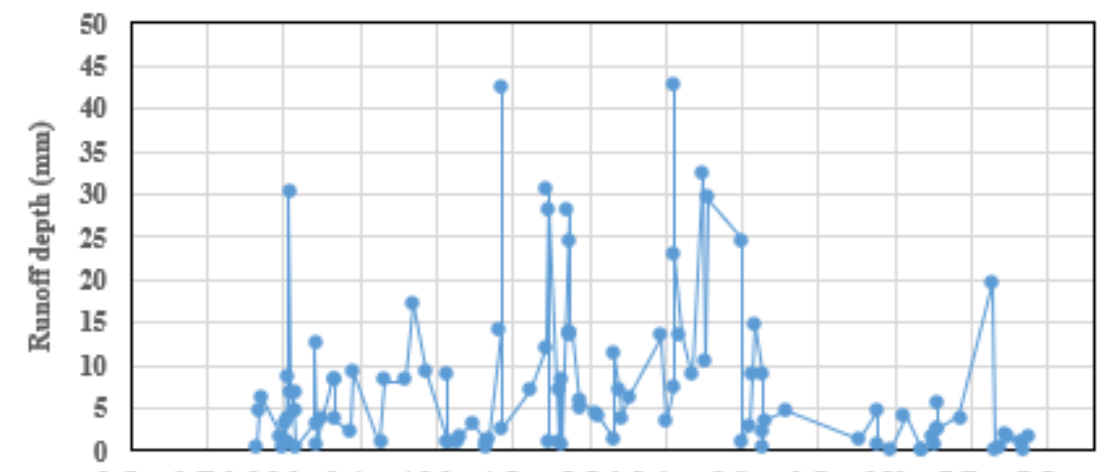

1-Jan 1-Feb 3-Mar3-Apr4-May 4-Jun 5-Jul 5-Aug 5-Sep 6-Oet 6-Nov 7-Dec 7-Jan
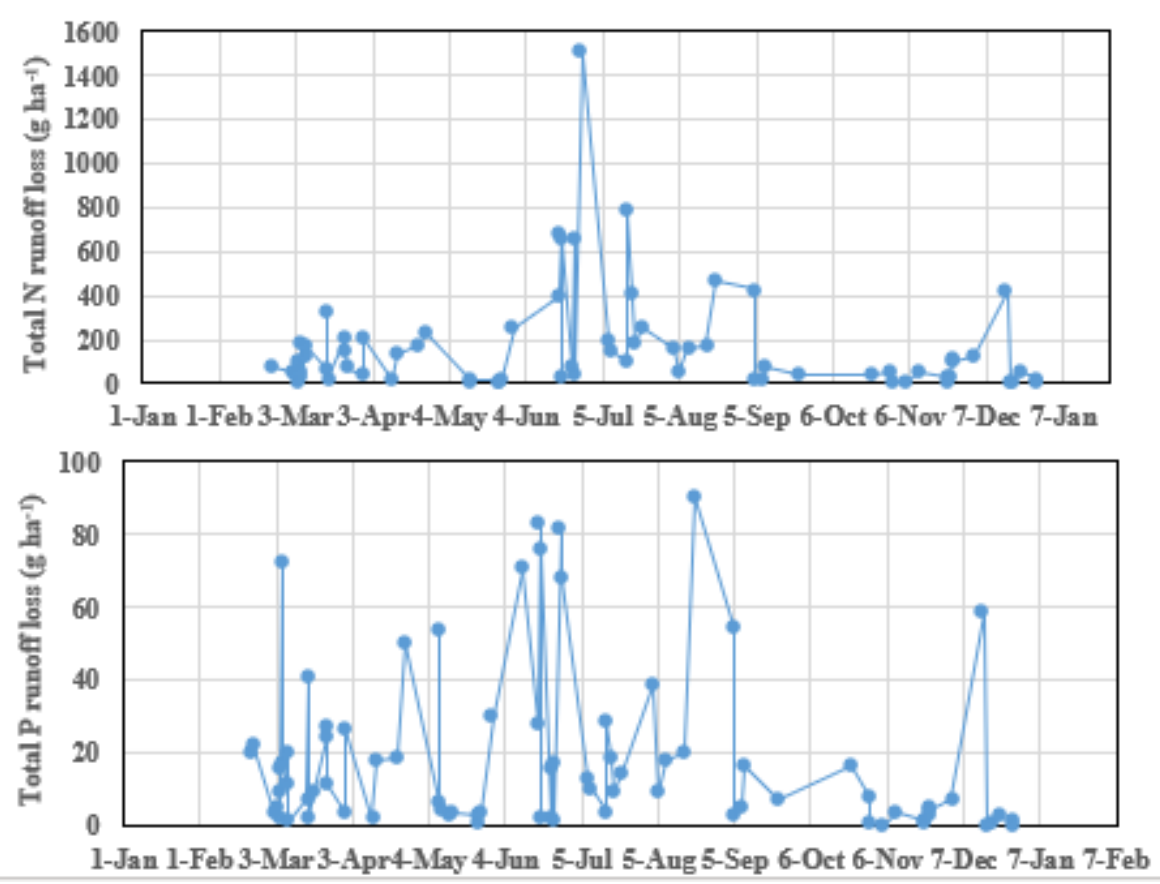

\section{Figure 4}

Temporal changes in (a) runoff depth and (b and c) nutrient runoff losses in the rice-planting area. 

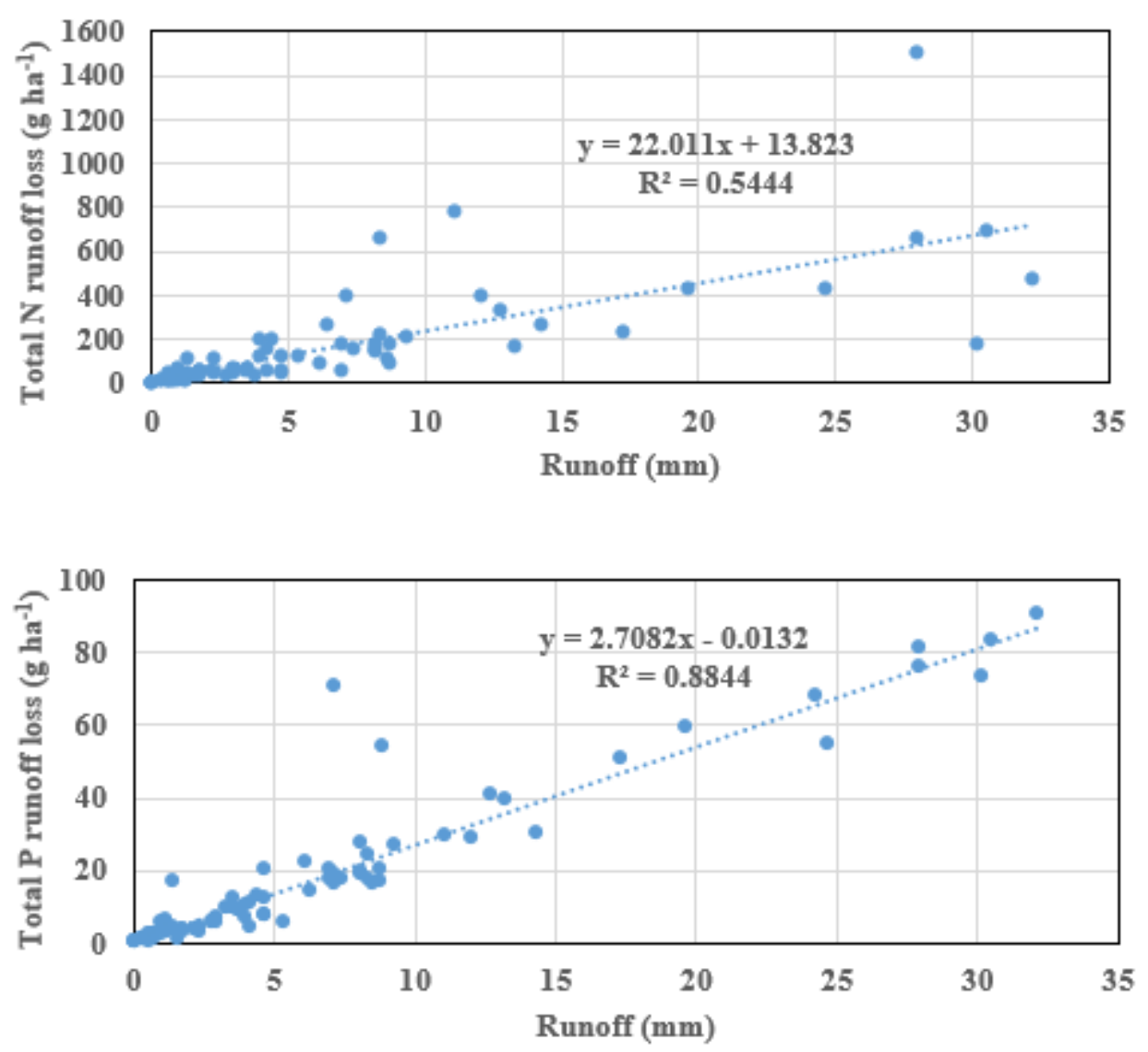

Figure 5

Relationship between nutrient runoff losses and runoff depth in rice-planting area.
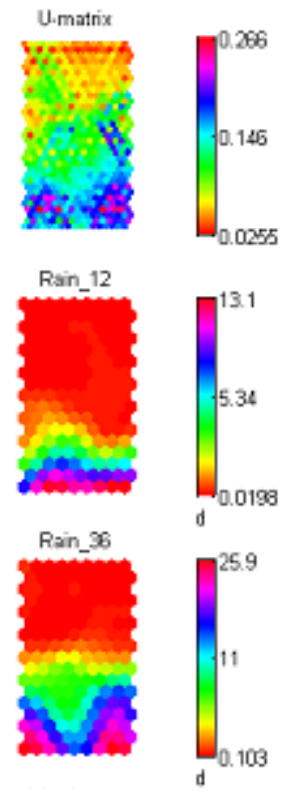
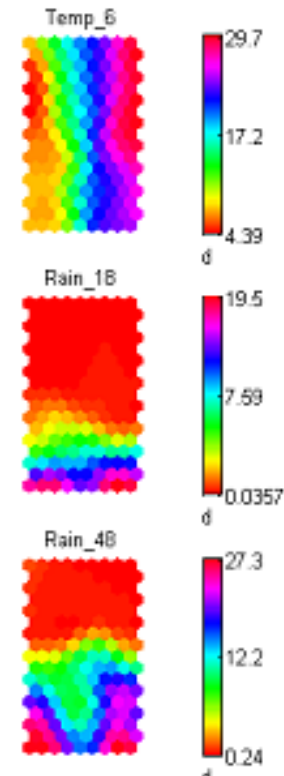
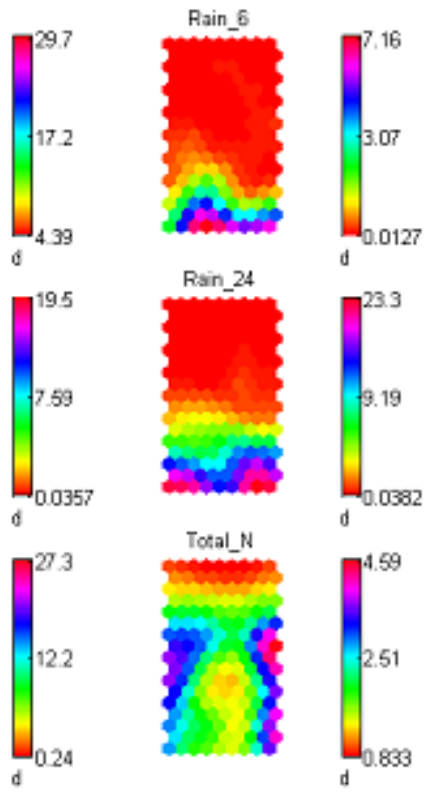

Total_N
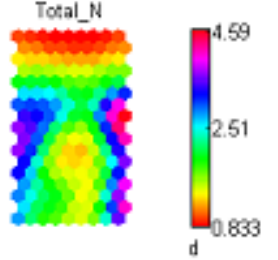

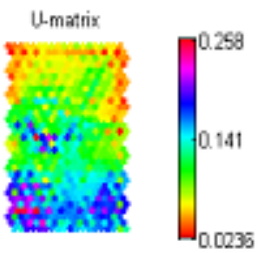

Rain_12
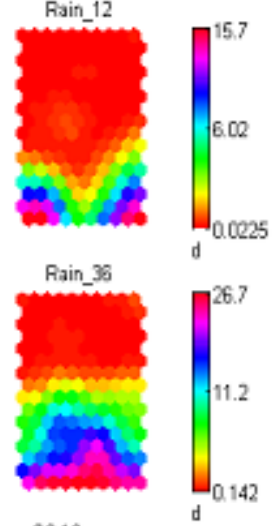

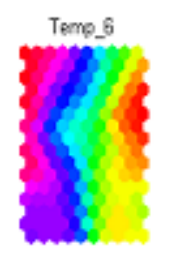

Rain_18

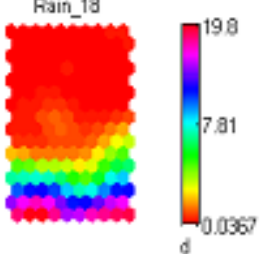

Rain_43

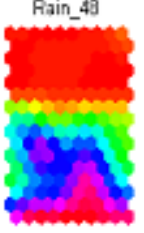

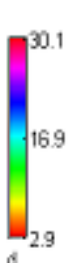
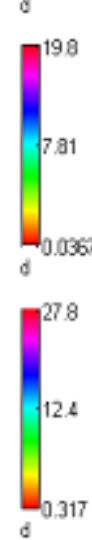
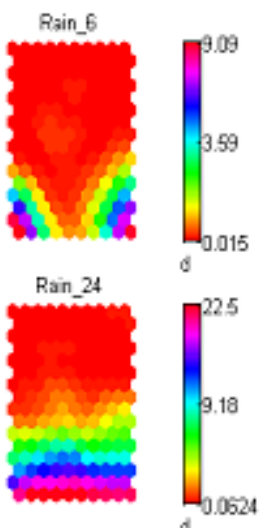

Total_P
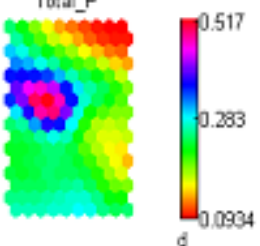

Figure 6

Visualization of rainfall and total $\mathrm{N}$ and $\mathrm{P}$ concentrations in the SOM map. 

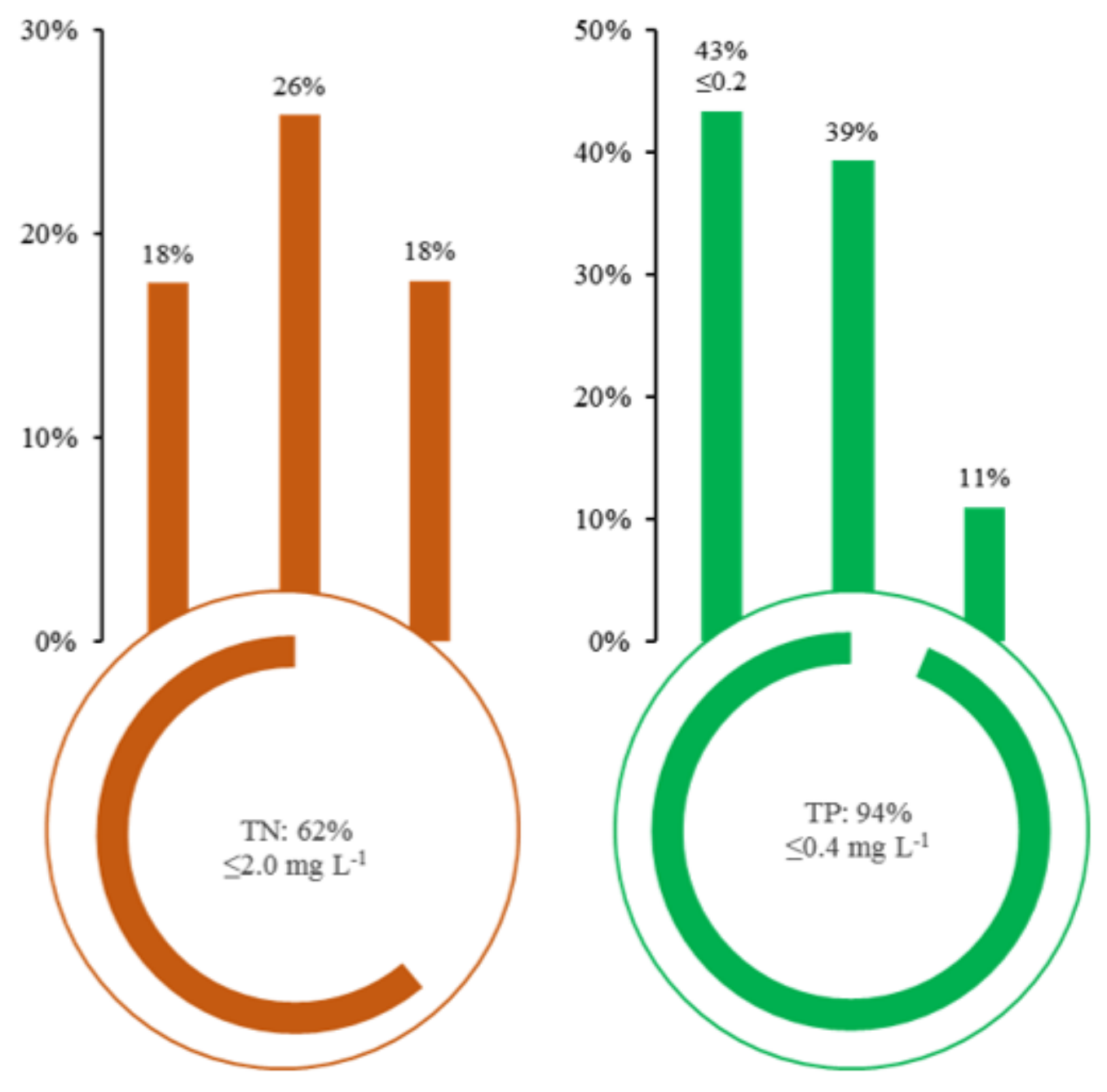

Figure 7

The distribution patterns of total $\mathrm{N}$ and total $\mathrm{P}$ concentrations over a planting year.

\section{Supplementary Files}

This is a list of supplementary files associated with this preprint. Click to download.

- formula1.PNG 